\title{
Small Intestine Cancer pT1b TNM Finding v7
}

National Cancer Institute

\section{Source}

National Cancer Institute. Small Intestine Cancer pT 1b TNM Finding v7. NCI Thesaurus. Code $C 89870$.

Small intestine cancer with tumor invading the submucosa. Note: The nonperitonealized perimuscular tissue is, for jejunum and ileum, part of the mesentery and, for duodenum in areas where serosa is lacking, part of the interface with the pancreas. (from AJCC 7th Ed.) 